\title{
The Impact of the Macroeconomic Environment on Pakistan's Manufacturing Sector
}

\section{Inayat U. Mangla* and Muslehud Din ${ }^{* *}$}

\begin{abstract}
This paper analyzes the impact of the macroeconomic environment on Pakistan's manufacturing sector, emphasizing in particular the role of fiscal and monetary policies in shaping incentives for industrial investment. Arguably, Pakistan's macroeconomic fundamentals in the last two decades have remained fragile, resulting in severe macroeconomic imbalances that have contributed to macroeconomic instability and hampered private investment in aggregate as well as in the manufacturing sector. Furthermore, macroeconomic stabilization policies have often failed to produce the desired results owing to the lack of coordination between monetary and fiscal policies. Pakistan's economy has thus lived on borrowed money and time and on rent-seeking behavior. Although some recent macroeconomic indicators have improved slightly, fundamental weaknesses remain. In particular, the recent improvement in the current account deficit was driven largely by the high inflow of remittances, coupled with financial engineering such as loan payments from the International Monetary Fund, "friendly" money, European Union bonds, and Islamic sukuk. It is imperative to think about the consequences of a leveraged reliance on remittances in the aftermath of falling oil prices and global deflation. Prudent macroeconomic management aimed at consolidating public finances and controlling inflationary pressures is essential to boost industrial investment and yield sustainable growth.
\end{abstract}

Keywords: Pakistan, economic activity, fiscal and monetary policies, manufacturing activity.

JEL classification: L69, O23.

\section{Introduction}

The share of the manufacturing sector in Pakistan's overall GDP in recent years has ranged from 14 to 16 percent, ranking third after

\footnotetext{
* Professor of Finance and Commercial Law, Haworth College of Business, Western Michigan University, Kalamazoo, MI.

** Consultant, Pakistan Institute of Development Economics, Islamabad.

We are grateful to the Haworth College of Business for partial financial support for travel purposes and to Dr Nasir Iqbal for helping us collect the data used in this study.
} 
services (51 percent) and agriculture (21-22 percent). Although the macroeconomic environment appears to have had little impact on the performance of the manufacturing sector, this would be an incomplete observation. Our basic premise in this paper is that macroeconomic policies and industrial policy in Pakistan have seriously affected the performance of its components, including the manufacturing sector, and vice versa. Testing this hypothesis requires using Granger causality: to put it simply, does the aggregate economy's performance influence its components or do its components affect the macro-aggregate?

The performance of Pakistan's manufacturing sector has followed a boom-bust growth cycle. At a time when the BRICS emerging economies have succeeded in establishing well diversified and internationally competitive manufacturing sectors, Pakistan's manufacturing sector has struggled to grow in a sustained manner and is still plagued by a host of structural problems, including low productivity and lack of innovation in product and process technologies.

The irony is that, despite the last seven years of democratic rule in Pakistan and the so-called pro-business regime in recent years, most economic indicators still reflect "below-par performance" (see Institute for Policy Reforms, 2015). In FY2015, the economy did not meet any targeted macro-indicators such as GDP growth, electricity production, federal revenues, circular debt, or net investment inflows. Worse still, the manufacturing sector lacks diversification with textiles and food still accounting for the bulk of the sector's total value added.

It is worth mentioning that some earlier studies attribute the lackluster performance of the manufacturing sector to several problems, including too much concentration in industrial products, lack of quality products, inadequate exposure to foreign markets and thus to competition, slow human development growth, inadequate investment, and lack of research and development. While much has been written on the performance and problems afflicting the manufacturing sector, ${ }^{1}$ little attention has been paid to the question of how the macroeconomic environment affects manufacturing sector performance.

This paper is a step in that direction. Specifically, it attempts to explore the role of the macroeconomic environment in driving private investment in the manufacturing sector. A stable and predictable

${ }^{1}$ See, for example, Ara (2004), Haque (2014), Kalim (2001), Kemal (1998), and Pasha, Pasha, and Hyder (2002). 
macroeconomic environment is essential for the sector to grow and remain competitive. A stable macroeconomic environment facilitates private investment in manufacturing by ensuring a business climate characterized by access to affordable financing through well-developed financial markets, predictable tax and public expenditure policies, and smooth long-term regulatory business planning in a low-inflation environment. On the other hand, an unstable macroeconomic environment with high inflation and high levels of fiscal deficit retards private investment, thus depressing industrial growth.

Section 2 gives a historical perspective on Pakistan's manufacturing sector, focusing in particular on its growth performance. Section 3 provides an overview of the macroeconomic environment. Section 4 focuses on the role of monetary and fiscal policies in influencing the performance of the manufacturing sector. Section 5 concludes the study and provides some tentative suggestions.

A common thread running through studies such as Haque (2014) and Amjad and Burki (2013) is their emphasis on the micro rather than the macro-economy: "small" in economies under stress (which Pakistan is) needs more attention than the big picture. However, one cannot ignore the basic pillars of growth and development: macro-stability, structural reforms (changes), and well-functioning institutions are key to Pakistan's growth. Thus, our main focus in this paper is still "macro-stability."

While Amjad and Burki (2013) provide a ray of hope for moving Pakistan's economy forward, Haque's (2014) analysis, which is based on past performance, is more cautious and proposes a tall order for the major stakeholders of the economy. Pakistan's competitiveness disadvantage in the 21st century emanates largely from its low and slow-growing economy. Thus, the country must overcome its lack of technology-intensive industries - a factor that has also held back progress in sectors that contribute the most to the economy, such as agriculture and services.

Haque's (2014) prescription is that "Pakistan must, before else, agree on the general direction of its industrialization. This is as much a political as an economic exercise requiring consensus building among (several) stakeholders." His recommendation calls for a fundamental rethinking of industrial policy. If history is any guide to Pakistan's future, we concur largely with this view and without putting words in the author's mouth, argue that Pakistan needs to focus more on its agriculture sector and small-scale manufacturing related to agro-business. Our skepticism is based on the frequent policy changes that characterize 
Pakistan's economy, lack of policy coherence, absence of any long-term commitment to particular policies or frameworks, incompetence, corruption, and a sector-specific expertise in the past.

The recent MOU signed with China, which has agreed to invest in an economic corridor, will bring some stable form of governance. However, this is a big "if." As the Business Recorder notes: "Our politicians lack willingness or vision to achieve a sensible balance between income, capital and consumption taxes. They serve bureaucrats who conventionally go for ill-designed social programs convincing politicians that these would attract more votes" (31 May 2015).

\section{A Historical Perspective on Pakistan's Manufacturing Sector}

Given that the sector started virtually from scratch at the time of independence, industrialization in Pakistan has made significant strides. The share of the manufacturing sector in GDP rose gradually from 10.37 percent in the 1950s (large scale, 5.04 percent; small scale, 5.34 percent) to 17.47 percent in the 2000s (large scale, 11.85 percent; small scale, 5.62 percent). Table 1 shows that there has been significant development in the manufacturing sector, especially in large-scale industry, whereas the share of small-scale industry has almost stagnated. This is attributable to industrial policies that have favored the establishment of large-scale industries while historically neglecting the small-scale sector. A clear policy debate in Pakistan is needed to foster small and medium enterprises, given the structure of Pakistan's economy (see Chaudhry \& Andaman, 2014).

Table 1: Percentage share of manufacturing in GDP and growth rate

\begin{tabular}{lcccccc}
\hline Period & \multicolumn{3}{c}{ Percentage share in GDP } & \multicolumn{3}{c}{ Real growth rate } \\
\cline { 2 - 7 } & $\begin{array}{c}\text { Total } \\
\text { manuf. }\end{array}$ & $\begin{array}{c}\text { Large } \\
\text { scale }\end{array}$ & $\begin{array}{c}\text { Small } \\
\text { scale }\end{array}$ & $\begin{array}{c}\text { Total } \\
\text { manuf. }\end{array}$ & $\begin{array}{c}\text { Large } \\
\text { scale }\end{array}$ & $\begin{array}{c}\text { Small } \\
\text { scale }\end{array}$ \\
\hline $1950 \mathrm{~s}$ & 10.37 & 5.04 & 5.34 & 7.76 & 15.75 & 2.30 \\
$1960 \mathrm{~s}$ & 14.91 & 10.65 & 4.26 & 9.93 & 13.39 & 2.91 \\
$1970 \mathrm{~s}$ & 16.52 & 12.33 & 4.19 & 5.50 & 4.84 & 7.63 \\
$1980 \mathrm{~s}$ & 16.65 & 12.26 & 4.38 & 8.21 & 8.16 & 8.40 \\
$1990 \mathrm{~s}$ & 17.18 & 12.15 & 5.02 & 3.89 & 3.54 & 4.87 \\
$2000 \mathrm{~s}$ & 17.47 & 11.85 & 5.62 & 7.34 & 7.70 & 7.69 \\
$1950-2010$ & 15.43 & 10.62 & 4.81 & 7.11 & 8.90 & 5.63 \\
\hline
\end{tabular}

Source: State Bank of Pakistan, Annual Report 2013-14.

On average, the sector's growth performance appears to be quite impressive. The manufacturing sector grew at an average annual rate of 
7.11 percent during 1950-2010, whereas the large-scale and small-scale sectors exhibited growth rates of 8.9 and 5.6 percent, respectively, during this period. Except for the 1970s and 1990s - dubbed the "lost decades" for manufacturing - the sector has grown at a healthy rate of 8 percent on average. Manufacturing industries grew at a rate of 7.7 percent during the 1950s while large-scale industry grew at a phenomenal rate of 15.8 percent. This acceleration in industrial growth is attributed to the industrial policy of the time, which aimed to establish consumer goods industries that relied heavily on domestic raw materials, including, for example, cotton, jute, and hides and skins. This policy was marked by direct controls on imports, private investment, and prices.

The growth of the manufacturing sector accelerated further to 9.9 percent during the 1960s. A number of initiatives helped realize this high growth rate, including a liberal import policy for raw materials and subsidies on exports through a number of schemes such as export bonus schemes, tax rebates, tax exemption, and export performance licensing. Protection rates during this period were fairly high, resulting in excessive business profits. Tax holidays and accelerated depreciation allowances to increase post-tax profits were also granted. Such policies were geared to attract private investment in the manufacturing sector at a time when the private sector was reluctant to undertake investment on a large scale.

Following this promising start, manufacturing growth fell sharply during the 1970s, with growth rates receding to 5.5 percent. This deceleration in industrial activity came on the back of the nationalization policies pursued at the time, which had a long-run impact on industrialization in Pakistan. With the nationalization of heavy industry, a number of sectors (including cement, fertilizers, oil refining, engineering, and chemicals) were transferred to the public sector with adverse consequences for private entrepreneurship, growth, and productivity. Industrialists faced a number of restrictions, including government-fixed prices under the Profiteering and Hoarding Act 1977. These measures heightened the uncertainty of the business environment, resulting in a fall in private investment and in capital flight.

The 1980s witnessed a reversal of the control policies of the previous decade. A process of deregulation and denationalization was initiated and various measures were taken to restore investor confidence. Administrative controls gave way to market-oriented forces, import policies were liberalized, tariff structures were rationalized, the par value of the rupee was brought closer to its equilibrium value and made 
convertible on the capital account. Simultaneously, investment licensing was no longer required and prices were de-controlled. Such marketfriendly policies helped industrial growth accelerate to 8.21 percent during this period.

Although deregulation continued into the 1990s, industrial growth slowed down to 3.9 percent while growth in large-scale manufacturing plummeted to an annual average rate of 3.54 percent. A number of factors were responsible for this depressed growth rate in the industrial sector, including political instability, deteriorating law and order, reduced protection rates, the emergence of significant infrastructure bottlenecks, an inadequate power supply coupled with frequent power outages in the early 1990s, and a sharp increase in energy prices in later years.

The manufacturing sector regained momentum in the 2000s with an average annual growth rate of 7.3 percent, to which both large-scale and small-scale manufacturing contributed. However, in recent years, the performance of the manufacturing sector has been marred by the crippling energy crisis, which has inflicted heavy losses in terms of productivity and competitiveness. In addition, poor domestic security has depressed private investment, generally subduing the manufacturing sector's performance.

One should not forget the effect of globalization and worsening terms of trade for Pakistan. Moreover, in the last two years in particular, a major concern is the continued slow growth in large-scale manufacturing. The rate of industrial growth in FY2015 is even smaller than the dismal 4 percent growth rate of the previous year. Public and private investment remains weak, tax collection is expected to be below target, and exports have declined in the face of an overvalued exchange rate. To maintain foreign reserves, the government has taken on substantial high-cost debt, which will put pressure on the external account by 2018 .

While the industrial sector has contributed to a respectable economic growth rate over the last several decades, it still lags significantly behind major competitors in Southeast Asia, let alone the BRICS group. Pakistan's manufacturing sector continues to face myriad constraints, including low levels of human capital, poor physical infrastructure, an uncertain policy environment, a prolonged power crisis, and poor security. Worse still, the industrial structure lacks diversification and is highly concentrated in a few industries: in 2000/01, more than 37.8 percent of the industrial value added was from food and 
textiles alone. Similarly, industries that are based exclusively on indigenous raw materials accounted for almost 60 percent of the value added, although their share of output has fallen over time. On the other hand, the share of chemicals was around 15 percent and that of electrical and nonelectrical machinery and transport equipment was just 9 percent.

\section{An Overview of the Macroeconomic Environment}

Macroeconomic stability is key to achieving robust economic growth on a sustained basis. Unfortunately, Pakistan's macroeconomic fundamentals have generally remained weak, making it difficult to maintain macroeconomic stability. Historically, the main source of the problem can be traced to persistent twin deficits in public finance and the external account, which leaves little flexibility for prudent macroeconomic management to support the growth momentum.

A look at the evolution of the external account is revealing. During 2005-09, Pakistan faced a burgeoning deficit in the current account, which jumped from 3.3 percent of GDP in 2005 to 9.2 percent in 2008 (Figure 1). The mounting current account deficit led to persistent pressure on the exchange rate, necessitating a tight monetary policy stance by the State Bank of Pakistan. In recent years, however, the current account deficit has contracted sharply and stood at 1.3 percent of GDP in 2014.

\section{Figure 1: Current account deficit (percent of GDP)}

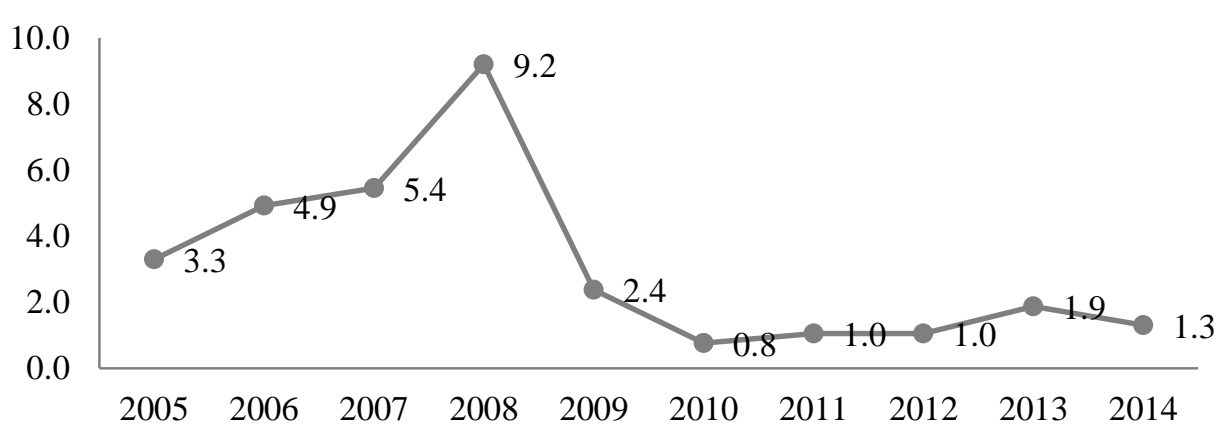

Source: State Bank of Pakistan, Annual Report 2013-14.

It is worth emphasizing here that the recent improvement in the current account deficit was driven largely by the high inflow of remittances coupled with political and financial engineering, such as payments from the International Monetary Fund (IMF), "friendly" money (what classical economists call Patinkin money), and bonds issued by the 
European Union and through Islamic sukuk. However, it is imperative to think of the possible consequences of a leveraged reliance on remittances in the aftermath of falling oil prices and global deflation. While remittances and global deflation in commodity prices have eased the pressure on Pakistan's twin deficits, one should not ignore the possible impact of a reversal of these trends on the capital account. The main implication of our analysis is that there will be continuing pressure on the country's foreign exchange resources.

Apart from the fragility of the external account, Pakistan also faces a high fiscal deficit and concomitant high inflation. During the 1980s, the fiscal deficit averaged 7.1 percent of GDP, falling only slightly to 6.9 percent during the 1990s (see Table 2). After showing some improvement in the mid-2000s, the fiscal deficit surged again, peaking at 8.2 percent of GDP. Invariably, high fiscal deficits have been accompanied by high rates of inflation. The rate of inflation averaged 7.2 percent in the 1980s, rising on average to 9.7 percent during the 1990s. After remaining subdued during the early 2000s, inflation climbed to 7.4 percent in 2003/04. Since then, Pakistan has faced persistent inflationary pressure with inflation remaining in double digits until 2010/11. In recent years, however, the inflationary pressure has eased mainly due to the fall in oil prices.

Table 2: Key macroeconomic indicators

\begin{tabular}{|c|c|c|c|c|c|c|c|}
\hline \multirow[t]{2}{*}{ Period } & \multirow{2}{*}{$\begin{array}{c}\text { GDP } \\
\text { growth } \\
\text { rate }\end{array}$} & \multirow{2}{*}{$\begin{array}{l}\text { Inflation } \\
\text { rate }\end{array}$} & \multirow{2}{*}{$\begin{array}{c}\text { Unemplo } \\
\text { yment } \\
\text { rate }\end{array}$} & \multicolumn{4}{|c|}{ As \% of GDP } \\
\hline & & & & Investment & $\begin{array}{l}\text { Fiscal } \\
\text { deficit }\end{array}$ & $\begin{array}{l}\text { Trade } \\
\text { deficit }\end{array}$ & M2 \\
\hline $1980 \mathrm{~s}$ & 6.5 & 7.2 & 1.4 & 18.7 & 7.1 & 8.9 & 39.2 \\
\hline $1990 \mathrm{~s}$ & 4.6 & 9.7 & 5.7 & 18.3 & 6.9 & 4.4 & 43.0 \\
\hline $2000 / 01$ & 2.0 & 3.1 & 6.1 & 17.2 & 4.3 & 1.8 & 36.2 \\
\hline $2001 / 02$ & 3.2 & 3.3 & 7.8 & 16.8 & 4.3 & 0.4 & 39.6 \\
\hline $2002 / 03$ & 4.8 & 2.9 & 7.8 & 16.9 & 3.7 & 0.5 & 42.6 \\
\hline $2003 / 04$ & 7.4 & 7.4 & 8.3 & 16.6 & 2.3 & 1.2 & 44.1 \\
\hline $2004 / 05$ & 7.7 & 9.1 & 7.7 & 19.1 & 3.3 & 4.0 & 45.5 \\
\hline $2005 / 06$ & 6.2 & 7.9 & 7.6 & 22.1 & 4.3 & 6.5 & 44.7 \\
\hline $2006 / 07$ & 4.8 & 7.6 & 6.2 & 22.5 & 4.4 & 6.6 & 46.9 \\
\hline $2007 / 08$ & 1.7 & 20.3 & 5.2 & 22.1 & 7.6 & 9.0 & 45.8 \\
\hline $2008 / 09$ & 2.8 & 13.6 & 5.2 & 19.0 & 5.2 & 7.8 & 40.3 \\
\hline $2009 / 10$ & 1.6 & 13.9 & 5.5 & 15.8 & 6.2 & 6.5 & 39.4 \\
\hline $2010 / 11$ & 2.7 & 11.9 & 6.0 & 14.1 & 6.5 & 4.9 & 37.0 \\
\hline $2011 / 12$ & 3.5 & 9.7 & 6.0 & 15.1 & 6.8 & 7.0 & 38.0 \\
\hline $2012 / 13$ & 4.4 & 7.7 & 6.2 & 14.6 & 8.2 & 6.6 & 39.0 \\
\hline $2013 / 14$ & 5.4 & 8.6 & 6.2 & 14.0 & 5.5 & 5.0 & 39.0 \\
\hline
\end{tabular}

Source: Pakistan Economic Survey 2013-14. 
To capture the overall macroeconomic situation of the country, we construct a macro-instability index comprising three core stability indictors: inflation, the fiscal deficit, and exchange rate variability (Figure 2). The index shows that, except for a brief period during the mid-2000s, the macroeconomic environment has remained largely unstable on the back of high current account and fiscal deficits and a high rate of inflation.

Figure 2: Macroeconomic instability index for Pakistan

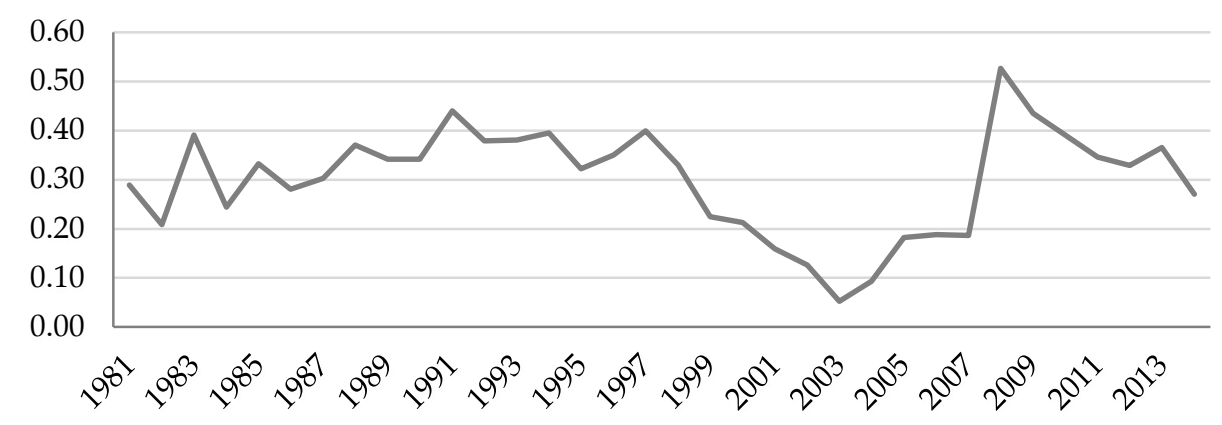

Source: Authors' calculations.

The 1980s were marked by major shifts in economic policy toward privatization, deregulation, and liberalization. Pakistan's transition to the managed float system of exchange rate management led to a 20 percent depreciation in the rupee. During this decade, the fiscal deficit remained about 6.8 percent of GDP on average, whereas the primary deficit ${ }^{2}$ on average was recorded at 3.5 percent of GDP. The current account deficit on average remained 2.8 percent of GDP - lower than during the 1970s, mainly due to high inflows of remittances and low import demand.

The macroeconomic environment worsened during the 1990s. Various policy measures, including trade liberalization, financial reforms, and tariff reforms, were implemented in the first half of the decade, but the economy failed to achieve macroeconomic stability due to the country's own political instability, the deteriorating law and order situation, and inconsistent macroeconomic policies. This instability was accentuated when Pakistan's foreign currency accounts were frozen, followed by the military takeover in 1999, which created uncertainty in the macroeconomic environment. The failure of the government to manage the fiscal as well as current account deficit led to unsustainable

2 The primary deficit excludes interest payments on debt. This is misleading ("cooking the books") because it implies one need not worry about debt and interest payments. 
and unprecedented levels of public debt during this period. Exchange rate variability and the vulnerability of foreign reserves increased significantly while high inflation and the high budget deficit persisted, with an adverse impact on macroeconomic stability.

In the early 2000s, the economy witnessed a turnaround: both inflation and the budget deficit fell, following significant foreign capital inflows, including remittances and foreign assistance. This macroeconomic stability was, however, short-lived as the economy began to experience fiscal and external sector imbalances amid an adverse security situation owing to the war on terrorism.

The relatively better performance of the Musharraf regime was not accompanied by any significant direct or foreign investment in the manufacturing sector; the focus of investment remained on real estate. The situation was made worse by the global financial crisis and by high food and oil prices, which contributed to inflationary pressures in the economy. The period also witnessed an expansionary fiscal policy on the back of increased spending on the Public Sector Development Program (PSDP). The rate of inflation spiraled from 7.8 percent in 2006/07 to 20.8 percent in 2008/09; the budget deficit increased from 4.3 percent of GDP in 2006/07 to 7.6 percent of GDP in 2007/08.

More recently, Pakistan's macroeconomic indicators have begun to show some improvement: the inflation rate has stabilized due mainly to the fall in oil prices, while the fiscal deficit has come down to 5.5 percent of GDP in 2014 from 8.2 percent in 2013. The exchange rate has also stabilized, financial engineering having eased the pressure on the external account. While it may be tempting to see the stability of the rupee as a sign of economic strength, it is worth noting that the State Bank of Pakistan is using precious foreign exchange reserves - mostly borrowed money - to shore up the value of the rupee.

\section{Macroeconomic Policies: Implications for the Manufacturing Sector}

This section analyzes the implications of macroeconomic policy, in particular monetary and fiscal policies, for the performance of the manufacturing sector. It is imperative to prevent a decline in manufacturing output not only to sustain growth, but also to increase the share of exports to maintain the sector's external competitiveness. For 1976-2003, the data show that real growth in manufactured exports followed a declining trend and remained highly volatile. Here, we restrict 
our attention to the period after the 1990s to highlight the most recent and current issues in macroeconomic management with reference to its implications for the performance of the manufacturing sector.

In the early 2000s, the manufacturing sector exhibited robust growth on the back of strong domestic demand amid relative macroeconomic stability and low inflation (Amjad, Din, \& Qayyum, 2011). As discussed in Section 3, this period was characterized by stable macroeconomic fundamentals, which contributed to the strong growth momentum in the manufacturing sector. In particular, a relatively easy monetary policy stance enabled buoyant consumption while, at the same time, lowering the cost of capital and boosting private investment in the manufacturing sector. Private investment increased from 16.8 percent of GDP in 2001/02 to a peak of 22.5 percent in 2006/07. However, this period of high growth and low inflation was disrupted by the global hike in food and oil prices, which added quickly to inflationary pressures in the economy. As macroeconomic imbalances began to emerge, the government adopted a tighter monetary policy to curb inflationary pressure and help stabilize the economy.

Macroeconomic stability proved elusive: a confluence of factors, including food and commodity price shocks, an unprecedented energy crisis, and poor law and order contributed to a sharp slowdown in economic growth (Mangla \& Uppal, 2014). The situation was worsened by the global financial crisis, which led to a sharp fall in foreign exchange earnings and the consequent drawdown of foreign exchange reserves.

On the domestic front, low economic growth contributed to fiscal pressures on the back of falling revenues. Consequently, the fiscal deficit climbed from 4.3 percent of GDP in 2001/02 to a peak of 7.6 percent in $2007 / 08$. As the twin deficits mounted, Pakistan was compelled to resort to IMF support for its balance of payments, which entailed conditionalities such as a tighter monetary policy and contractions in the fiscal deficit. The government slashed the PSDP by PRs 150 billion, while the monetary policy discount rate was raised to 15 percent. These contractionary policies depressed private investment and economic growth plummeted to 1.7 percent in $2007 / 08$.

These macroeconomic developments had an adverse impact on the manufacturing sector. To begin with, the tight monetary policy raised the cost of capital, thus severely constraining private investment. At the same time, domestic demand began to subside while exports plunged as 
a result of the global financial meltdown. Consequently, growth in manufacturing fell sharply. The rising fiscal deficit also crowded out private investment in a high-interest rate environment. Worse still, in an effort to reign in the fiscal deficit, the government cut public spending on critical development needs, including physical infrastructure, which compounded the constraints to the manufacturing sector.

A key area of concern in macroeconomic management is the lack of coordination between monetary and fiscal policies. This allowed inflation to persist, despite contractionary demand management policies. Specifically, despite the fact that a tight monetary policy stance kept the policy discount rate high, the failure to contain nonproductive public spending ignited inflationary pressures, thus nullifying the policy's impact on the rate of inflation. The continuing high rate of inflation raised the cost of inputs and eroded private profit margins, thereby impeding growth in the manufacturing sector.

After remaining in double digits for a consecutive 21 months, inflationary pressures eased somewhat and the rate of inflation came down to single digits in 2009. This prompted the monetary authorities to ease the monetary policy, which had been blamed for stifling the growth momentum in the manufacturing sector. Further impetus for loosening the monetary policy stance came from some improvement in macroeconomic fundamentals as the pressure on the current account eased owing to strong remittances and a slight uptick in the growth of manufacturing output.

Although the State Bank lowered the discount rate to 12.5 percent in November 2009, industrial output failed to pick up substantially due to a combination of factors, including the hike in domestic power and gas tariffs, the fragile domestic security situation, and crippling energy shortages. In its efforts to revive economic growth, the government resorted to fiscal expansion, almost doubling the PSDP from PRs 219 billion in 2008/09 to PRs 421 billion in 2009/10 in budgetary terms. This fiscal expansion, at a time of weak economic fundamentals, proved detrimental to macroeconomic stability with adverse consequences for manufacturing output.

The rising fiscal deficit stoked inflationary pressures in the economy, with inflation reaching double digits once again in 2010. This persistence of inflation, despite a prolonged tight monetary policy, was due mainly to the monetization of the fiscal deficit, which contributed to 
higher-than-targeted growth in the money supply, in turn dampening the impact of higher interest rates on the rate of inflation. Inflationary expectations also remained stubborn, which eroded the effectiveness of monetary policy in curbing the rate of inflation. Other factors that contributed to the persistence of inflation included supply disruptions in the wake of widespread floods and spiraling energy prices. Not coincidentally, industrial production, after a slight improvement in 2009, fell by 2.3 percent in 2010 .

In this high-interest rate environment, the demand for credit to the private sector remained sluggish and was also constrained by banks' increasing appetite for risk-free government securities (Pakistan Investment Bonds). The latter carried a high rate of interest, making lending to the private sector an unattractive option. The increase in demand for government securities also reflected banks' increasing risk aversion in the face of mounting nonperforming loans in their portfolios.

In essence, the combination of a tight monetary policy and higher fiscal deficits financed through central bank borrowing crowded out private investment, thus hampering industrial expansion. These policy developments up to 2012 led Pakistan to another round of external imbalances and depletion of foreign reserves, culminating in a foreign reserves shock in 2013. The country's vulnerability to default led to a fifth IMF bailout, in this case, a longer-term loan facility of US\$ 7.5 billion.

Pakistan's macroeconomic imbalances are driven by deep-seated structural problems, including a narrow tax base, cash-bleeding stateowned enterprises, and low rates of saving and investment, all of which contribute to a persistent domestic resources gap. On the external front, the balance-of-payments position remains precarious, due mainly to the lack of export competitiveness, which forces the country to rely on external financing.

Addressing these structural issues is critical if Pakistan is to achieve macroeconomic stability, which is a prerequisite for attracting domestic and foreign investment in the manufacturing sector. In particular, there is a need to strengthen public finances by widening the tax base, improving tax collection through administrative reforms in the tax collection machinery, and prudent public expenditure management. Moreover, it is essential to restructure or privatize state-owned enterprises to plug the massive leaks of public funds. 
The main implication of our analysis is that there will be continuing pressure on the country's foreign exchange resources. Given this, there has to be a debt reduction strategy in place and the national budget should not be used only to feed current expenditures. Pakistan's exports are highly concentrated in a few products, making its exports very vulnerable to external demand shocks with adverse consequences for the balance of payments. A comprehensive strategy designed to improve the country's export competitiveness and product diversification would go a long way toward strengthening the balance of payments position, which is essential to maintain macroeconomic stability.

A sustained improvement in macroeconomic fundamentals would be instrumental in boosting economic activity in the manufacturing sector, which is essential for job creation and poverty reduction. In particular, better fiscal management through the rationalization of current expenditures and diversion of public resources to development spending (including on physical infrastructure) would attract industrial investment. Similarly, better fiscal discipline would allow the State Bank of Pakistan to achieve its monetary targets and contain inflationary pressures in the economy. These measures would create a stable and predictable macroeconomic environment, which the manufacturing sector needs if it is to shift onto a robust growth trajectory.

The country's deteriorating security situation has also led to a significant decline in foreign investment in the energy sector as well as in the overall economy. It is appalling to note that, in a globally integrated economy and global liquidity environment, net foreign direct investment (FDI) in Pakistan for 2008-14 ranged from US\$ 5.4 billion to a low of US\$ 0.8 billion. The oil and gas sector contributed 39 percent to FDI in FY2013 as compared to 77 percent in 2012, mainly due to worsening law and order in Balochistan and Khyber Pakhtunkhwa where exploration activities have contracted. However, it is encouraging to see a fresh inflow of FDI in the energy sector in 2014 of US $\$ 1.2$ billion (Business Recorder, 2 February 2014).

Where does Pakistan stand today, in terms of FDI inflows? The Business Recorder newsletter has this to offer (18 March 2015):

According to latest FDI numbers released by the State Bank of Pakistan, net FDI inflow stood at about $\$ 75$ million in February - a manifold growth over the inflow of $\$ 16$ million in the month before. However, on year-on-year 
basis, net FDI inflows dropped by 14 percent in February 2015. Total FDI inflows for the first eight months of current fiscal year now stands at $\$ 620$ million about 3 percent lower than the comparable period last year. Interestingly a bulk of FDI inflows have come from China and UAE - a little more than half actually - whereas that from other countries such as United States, the UK, Switzerland and Hong Kong have dropped substantially. Net FDI outflows from Saudi Arabia have worsened over last year, whereas all that Pak-Turkey investment brotherliness also hasn't bore any fruits as yet $[\mathrm{sic}] .^{3}$

It is also worth mentioning that FDI outflows have grown more than FDI inflows. The data released by the State Bank show that, so far, inflows have risen by 26 percent whereas gross outflows increased by 52 percent. If we exclude an estimated profit repatriation amount of US\$ 550 million, net capital account inflows amount to little more than chip change. Unsurprisingly, the KSE index recently displayed its worst performance in Pakistan's history.

\section{Conclusion and Some Suggestions}

Pakistan's manufacturing sector has followed boom-bust cycles of growth, primarily as a result of persistent twin deficits in public finance and the external account. This has left little room for prudent macroeconomic management to support the growth momentum. Pakistan also faces a high fiscal deficit and concomitant high inflation. The macroinstability index we have constructed (comprising inflation, the fiscal deficit, and exchange rate variability) shows that, except for a brief period during the mid-2000s, the macroeconomic environment has remained largely unstable on the back of high current account and fiscal deficits and a high rate of inflation.

Pakistan's competitiveness disadvantage emanates largely from its slow growing economy. Over the past 20 years, its generally fragile macroeconomic fundamentals have resulted in severe macroeconomic imbalances; these, in turn, have contributed to macroeconomic instability and hampered private investment in aggregate as well as in manufacturing. Macroeconomic stabilization policies have often failed to produce the desired results owing to the lack of coordination between

\footnotetext{
${ }^{3}$ http://www.brecorder.com/br-research/44:miscellaneous/5274:fdi-inflows-or-chip-change/
} 
monetary and fiscal policies. Prudent macroeconomic management aimed at consolidating public finances and controlling inflationary pressures is essential to boost industrial investment and economic growth.

The country must reassess its macroeconomic priorities within the framework of conventional wisdom concerning fiscal and monetary policies. Despite its persistent failure in what we call " $4+4+3$ " regimes since 1970, Pakistan's poor performance stems from its inability to integrate with (and take advantage of) the fast pace of globalization. In a globally competitive world, Pakistan has to find a niche sector - perhaps the SME sector, which is the mainstay of the economy in terms of value addition, employment, living standards, and exports. Realistically, any worthy economist of our generation would be hard pressed to declare the country's macroeconomic situation in general and industrial policy in particular as being "satisfactory and sustainable." We have argued that Pakistan's macroeconomic policies are inherently inconsistent and ad hoc, and this has contributed significantly to the current crisis in manufacturing and in other sectors of the economy.

While Pakistan's exports have been dominated by the textiles and garments sector, their combined share has fallen from about 75 percent of total exports in 2001 to 55 percent in 2010. On the other hand, the SME sector's exports have increased steadily, with the bulk of SME units operating in industrial clusters around Karachi, Lahore, and the SialkotGujrat-Gujranwala triangle in central Punjab. In the agriculture sector, Rashid and Burki (2013) identify cotton as a potential driver along with high-valued nontraditional agriculture exports.

The conclusions presented above are "sufficient conditions." Equally important are the "necessary conditions" outlined below:

- Pakistan's macro and manufacturing problems are perhaps equally noneconomic, and then structural and/or cyclical.

- To borrow a famous political phrase from the US Clinton campaign in 1991, "it's the economy, stupid." It is the political economy and not the economy of Pakistan that is "stupid." Pakistan's macro-economy has lived on borrowed money and time, and rent-seeking behavior.

- Most policies work ad hoc. There are not enough political and economic think-tanks where policy formulation is discussed and debated before policies are finalized and implemented with firm commitment. 
- We live in a global economy, one from which Pakistan has isolated itself in real terms (for well-known reasons) and failed to capitalize on the benefits of globalization in its macro-financing activities.

- Political and financial engineering strategies only make a marginal difference, but do not resolve the fundamental economic problems of poor governance and corruption.

- Pakistan has "ego" problems and often sets inappropriate benchmarks, e.g., the rupee exchange rate, trade with India, and the construction of dams. In mid-February 2015, for example, the country virtually shut down for a week for the sake of a cricket match with India (which the former lost). It would be more prudent for Pakistan to set benchmarks vis-à-vis India's ITT's and other corporate entities.

- Stability in law and order is fundamental for any macroeconomic improvement.

- Pakistan's institutions have weakened, rather than strengthened, over time. Notable among these are the financial sector, given issues of autonomy among the State Bank, commercial banks, and other financial institutions. In the education sector, an example worth noting is the Higher Education Commission, which dictates how many credit-hours and courses are to be taught per semester, even as Pakistan's public sector institutions continue to churn out graduates without providing them the technical skills needed in a 21st century competitive environment. 


\section{References}

Ahmed, H., \& Hamid, N. (2014). Patterns of export diversification: Evidence from Pakistan [Special edition]. Lahore Journal of Economics, 19, 307-326.

Ahmed, M. (2010, January 20). Blaming the IMF. The News. Retrieved from http:/ / www.thenews.com.pk/TodaysPrintDetail.aspx?ID=219637\& Cat $=9 \& \mathrm{dt}=1 / 20 / 2010$

Amjad, R. (2005). Skills and competitiveness: Can Pakistan break out of the low-level skills trap? Pakistan Development Review, 44(4), 387409.

Amjad, R. (2013). Economic management under Musharraf and coalition rule: Key lessons for sustainable growth. In R. Amjad \& S. J. Burki (Eds.), Pakistan: Moving the economy forward (chap. 3). Lahore: Lahore School of Economics.

Amjad, R., \& Burki, S. J. (Eds.). (2013). Pakistan: Moving the economy forward. Lahore: Lahore School of Economics.

Amjad, R., Din, M., \& Qayyum, A. (2011). Pakistan: Breaking out of stagflation into sustained growth [Special edition]. Lahore Journal of Economics, 16, 13-30.

Ara, I. (2004). Is Pakistan's manufacturing sector competitive? Pakistan Development Review, 43(4, Pt. 2), 685-706.

Chaudhry, A., \& Andaman, G. (2014). The need for a coordinated industrial strategy to boost Pakistani exports: Lessons from Asia [Special edition]. Lahore Journal of Economics, 19, 177-206.

Chaudhry, S. A. (2013). Pakistan's Indus Basin water strategy: Past, present, and future. In R. Amjad \& S. J. Burki (Eds.), Pakistan: Moving the economy forward (chap. 9). Lahore: Lahore School of Economics.

Felipe, J. (2007). A note on competitiveness and structural transformation in Pakistan (ERD Working Paper No. 110). Manila: Asian Development Bank. 
Hamdani, K. (2013). Benefitting from foreign direct investment. In R. Amjad \& S. J. Burki (Eds.), Pakistan: Moving the economy forward (chap. 11). Lahore: Lahore School of Economics.

Hamdani, K. (2014). Foreign direct investment and technological capabilities: The relevance of the East Asian experience for Pakistan [Special edition]. Lahore Journal of Economics, 19, 267-281.

Haque, I. (2007). Rethinking industrial policy (Discussion Paper No. 183). Geneva: United Nations Conference on Trade and Development.

Haque, I. (2010). Pakistan: Causes and management of the 2008 economic crisis (Global Economy Series No. 22). Penang, Malaysia: Third World Network.

Haque, I. (2014). Toward a competitive Pakistan: The role of industrial policy [Special edition]. Lahore Journal of Economics, 19, 61-90.

Haque, I., \& Amjad, S. (2012). Toward a heterodox approach: Reconciling stabilization and economic growth in Pakistan [Special edition]. Lahore Journal of Economics, 17, 1-32.

Hasan, P. (2013) Failed economic promise: Lessons from Pakistan's development experience. In R. Amjad \& S. J. Burki (Eds.), Pakistan: Moving the economy forward (chap. 2). Lahore: Lahore School of Economics.

Husain, I. (2013). Economic governance and institutional reforms. In R. Amjad \& S. J. Burki (Eds.), Pakistan: Moving the economy forward (chap. 10). Lahore: Lahore School of Economics.

Jain, S. (2013, October 24). India's central bank program brings in billions [Blog]. Wall Street Journal. Retrieved from http://blogs.wsj.com/indiarealtime/2013/10/24/indias-centralbank-program-brings-in-billions /

Kalim, R. (2001). Capacity utilization in the large-scale manufacturing sector: An empirical analysis. Lahore Journal of Economics, 6(1), 145160.

Kemal, A. R. (1998). Industrial development in Pakistan. Pakistan Journal of Applied Economics, 14(1-2), 107-119. 
Lall, S., \& Weiss, J. (2004). Industrial competitiveness: The challenge for Pakistan (Seminar Paper). Islamabad: Asian Development Bank.

Mangla, I. U. (2011). Reconstructing the performance of Pakistan's political economy: Another paradigm [Special edition]. Lahore Journal of Economics, 16, 31-70.

Mangla, I. U., \& Uppal, J. Y. (2014). Macroeconomic policies and energy security: Implications for a chronic energy-deficit country. Pakistan Development Review, 53(3), 255-274.

McCartney, M. (2014). The political economy of industrial policy: A comparative study of the textiles industry in Pakistan [Special edition]. Lahore Journal of Economics, 19, 105-134.

Pasha, H. A., Pasha, A. G., \& Hyder, K. (2002). The slowing down of the growth of total factor productivity in Pakistan (Research Report No. 44). Karachi: Social Policy and Development Centre.

Rahim, S. (2012). Industrialization by fitting in: Acquiring technology through collaboration and subcontracting [Special edition]. Lahore Journal of Economics, 17, 83-102.

Rodrik, D. (2004). Industrial policy for the twenty-first century (Faculty Research Working Paper No. 04-047). Cambridge, MA: Harvard University Press.

State Bank of Pakistan. (2014). Annual report 2013-14: State of the economy. Retrieved from http:/ /www.sbp.org.pk/reports/annual/arFY14/Anul-indexeng-14.htm 